\title{
The different faces of care work: understanding the experiences of the multi-cultural care workforce
}

\author{
MARTHA DOYLE** and VIRPI TIMONEN*
}

\begin{abstract}
An increased demand for long-term care services coupled with the decreased availability of informal (family) carers in many industrialised countries has led to the employment of growing numbers of 'migrant care workers'. Little is known about this heterogeneous group or of their experience of employment in longterm care. Providing an important insight into a hitherto little researched and poorly understood topic, this article presents the findings of a qualitative study in Ireland that sought greater understanding of migrant carers' experience of care work and of the intra-group differences among them. The findings suggest that some members of the long-term care workforce are more likely to confront obstacles and discrimination than others. The data indicate that the experiences of European, South Asian and African carers are significantly different and that relationships may exist between carers' region of origin and their experience of care work, employment mobility and long-term plans for remaining in the sector. The findings underscore the significance of acknowledging the unique barriers and obstacles faced by particular populations of care workers. A better understanding of the changing demographic profile and needs of both care recipients and their paid (migrant) care-givers is required to ensure that appropriate policy and practical interventions are developed to support both groups.
\end{abstract}

$\boldsymbol{K E Y} \boldsymbol{W} \boldsymbol{W} \boldsymbol{R} \boldsymbol{S}$ - long-term care, migrant carers, domiciliary care, institutional care, care workforce, discrimination.

\section{Introduction}

Population ageing, increasing female participation in the labour market, and the shift towards more formal (paid) care, alongside the continuing prevalence of informal (unpaid, family) care (Daatland and Lowenstein 2005), have affected the demand, supply and delivery of long-term care services in many industrialised countries (Stone and Wiener 200I; Organisation for Economic Co-operation and Development (OECD)

* Social Policy and Ageing Research Centre, Trinity College Dublin, Ireland. 
2005; European Foundation for the Improvement of Living and Working Conditions (EFILWC) 2006). These changes have generated and will continue to sustain increased demand for formal care services, which in turn necessitates an expansion of the long-term care workforce (US Bureau of Labor Statistics 2005). In the light of the care labour shortages apparent in many countries, the experiences of immigrant care workers will in the future attract more attention from policy makers and researchers (EFILWC 2006). These workers fill labour shortages not only in the formal care sector but also in the 'grey' labour market where carers are employed directly (and sometimes illegally) by families to complement or replace the family's informal care (Hondagneu-Sotelo 2000; Ungerson 2003; Degiuli 2007).

International research on migrant carers is still in its infancy and has tended to examine the experiences of externally-sourced carers through the lens of a single nationality. For example, McGregor (2007) recounted the experiences of Zimbabwean care workers in the United Kingdom, Parreñas (2000) the experiences of Filipino carers in Italy and the United States, and Yeoh and Huang (2000) analysed Filipino carers in Singapore. Research that has explored employers' perspectives on migrant carers has discerned racial stereotyping of carers with employers regarding certain nationalities as superior to others. In many instances, employers use the 'race card' to explain the apparently irrational desire of care workers to engage in low-paid, low-mobility jobs while still investing considerable emotional and personal energy in their work (Anderson 2006). The literature indicates that many employers and care recipients construct racial stereotypes and have a preference for certain nationalities that they regard as nurturing, docile, warm and caring (Anderson and Rogaly 2005; Yeates 2005). According to Bakan and Stasiulis (1995), the proliferation of this racial stereotyping in Canada is perpetuated by recruitment agencies that make judgements on what nationalities the care recipients (usually members of white, high-income families) perceive as being suitable caregivers. In this way, the agencies directly influence and perpetuate racial and ethnic stereotypes by determining the source countries of large numbers of domestic care workers.

Little research in Europe or elsewhere has explored whether the experiences of carers of different nationalities vary once employment has been secured. Degiuli (2007: 205) noted this gap in the literature and suggested that a better understanding is required of how 'the process of racialisation' influences migrant care workers' conditions of employment and mobility prospects. Our qualitative study sought to address this neglected area and to investigate whether there were intra-group differences among 'migrant care workers' in the Irish long-term care 
sector. In common with many European countries, such as Italy, Austria and the United Kingdom (Ungerson 2003; Degiuli 2007; McGregor 2007), migrant long-term care workers have become increasingly evident in Ireland. Their presence is novel for Ireland (which for centuries has been a country of emigration not immigration) and is a by-product of the country's economic success over the last I5 years. The migrants have brought about a rapid transformation of the long-term care workforce, and have unknowingly facilitated the introduction of a 'cash for care' scheme and the expansion of formal long-term care (Timonen, Convery and Cahill 2006; Ahern, Doyle and Timonen 2007). Furthermore, higher relative incomes and increased female labour-market participation rates (Central Statistics Office 2005) have reduced the availability of informal carers and encouraged the rise in the number of migrant care workers employed in the 'grey' labour market. These carers, who are outside the income tax net, typically receive cash-in-hand from their care recipient or the care-recipient's family. While official estimates of the presence and country of origin of non-Irish nationals in the long-term care sector do not exist, anecdotal and other evidence suggests that the majority of carers in institutional and domiciliary care settings, particularly in urban areas, are migrant workers (Irish Nursing Home Organisation (INHO) 2006; Doyle 2006).

\section{Design and methods}

Given the dearth of international and Irish research on unskilled and lowskilled migrant care workers, we decided to undertake the study reported here. The absence of a sampling frame appropriate for a quantitative survey and the lack of baseline data which could assist in the development of a survey instrument led us to reject a quantitative approach. Qualitative methods were also deemed preferable since carers employed in the 'grey' labour market could only be accessed by convenience sampling. Furthermore, the sensitive nature of the research questions provided us with a powerful reason to adopt a qualitative approach.

Between January and July 2007, 40 migrant carers employed in the Irish long-term care sector were interviewed. They were recruited with the assistance of migrants' organisations, through a small number of service providers (although their role in selecting the interviewees was minimised), and by snowballing. To explore intra-group differences, we purposively sampled those of African, South Asian and European origin, as there were good grounds to believe that their experiences differed (McGinnity et al. 2006) ${ }^{1}$. Thirty-two of the interviewees were employed in the formal care 
T А в L E I. Region and country of origin by employment sector of the interviewees

\begin{tabular}{lcc}
\hline $\begin{array}{l}\text { Region and } \\
\text { country of origin }\end{array}$ & $\begin{array}{c}\text { Formal } \\
\text { sector }\end{array}$ & $\begin{array}{c}\text { 'Grey' } \\
\text { care-labour } \\
\text { market }\end{array}$ \\
\hline Europe: & II & 2 \\
$\quad$ Lithuania & 3 & I \\
Poland & 6 & \\
French & I & I \\
Russia & I & 2 \\
Kurdistan & II & \\
Total & & 5 \\
South Asia: & II & \\
Philippines & & \\
Africa: & 5 & \\
Nigeria & 2 & \\
South Africa & I & \\
Cameron & I & I \\
Zimbabwe & I & 8 \\
Liberia & Io & \\
Mauritius & 32 & \\
Total & & \\
Total & &
\end{tabular}

T A B L E 2. Sector of care employment and region of origin of interviewees

\begin{tabular}{lccccc}
\hline \multicolumn{5}{c}{ Type of care employment } \\
\cline { 2 - 6 } $\begin{array}{l}\text { Region } \\
\text { of } \\
\text { origin }\end{array}$ & $\begin{array}{c}\text { Formal } \\
\text { carer - residential } \\
\text { institution }\end{array}$ & $\begin{array}{c}\text { Formal } \\
\text { domiciliary } \\
\text { carer }\end{array}$ & $\begin{array}{c}\text { Formal } \\
\text { live-in } \\
\text { domiciliary } \\
\text { carer }\end{array}$ & $\begin{array}{c}\text { 'Grey' labour } \\
\text { market live-in } \\
\text { domiciliary } \\
\text { carer }\end{array}$ & $\begin{array}{l}\text { 'Grey' labour } \\
\text { market } \\
\text { domiciliary } \\
\text { carer }\end{array}$ \\
\hline $\begin{array}{l}\text { Africa } \\
\text { South Asia }\end{array}$ & 4 & 6 & 0 & 0 & I \\
$\begin{array}{l}\text { Europe } \\
\text { Total }\end{array}$ & 7 & 0 & 5 & 5 & I \\
\hline
\end{tabular}

Note: Except for four male institutional care workers (3 Filipino and I African), all interviewees were female.

sector and eight in the 'grey' care-labour market. Table i provides a breakdown of the interviewees' country of citizenship/region of origin and legal employment status, while Table 2 categorises the carers by their region of origin and occupational classification. The semi-structured interviews lasted between one and two hours. Where consent was granted by the interviewee, the interviews were audio-recorded and transcribed. 
In the few cases when permission to tape-record the interview was declined, extensive hand-written notes were taken. The method of analysis adhered to the framework approach as characterised by Pope, Ziebland and Mays (2000).

The main limitations of the study lie in the fact that non-probability sampling methods were used to select a small proportion of the migrant care workforce, making it clearly impossible to generalise for the entire migrant care workforce in Ireland. Furthermore, the small sample has required us to cluster migrants by broad region of origin; that is, Africa, Europe and South Asia. Unfortunately, the size of the sample did not allow us to explore whether intra-regional differences influenced the experiences of the care workers. Despite these limitations, we believe that our study is a useful first step in identifying important facets of migrants' experiences of care work and exploring whether there are significant intragroup differences.

\section{Migrant care workers' experiences of the long-term care sector}

\section{African carers}

Of the io African carers interviewed, all but two had arrived in Ireland as asylum seekers. While none had completed third-level (or higher) education, one was a qualified nurse and several had worked in professional roles, as in banking, accountancy, fashion, administration and the retail sector in their countries of origin. Similar to McGregor's (2007) Zimbabwean carers, the African interviewees intimated that they had limited employment options and that access to care work was difficult. Frequently, they were required to complete intensive and costly (privately paid) training courses and initially to work unpaid on a 'voluntary' basis in order to 'get experience'. Even following such an intensive induction, they were offered highly irregular and unstable work. It was only after working in this capacity for several months that the prospective employer deemed them adequately suited and trained to work as a carer.

Once in employment, all but one South African carer had experienced some form of racism or prejudice. Perceptions of unfairness and underlying discrimination arising from such incidents were harboured by the carers, not towards care recipients, but about co-workers and managers who colluded in, or tacitly accepted, such behaviour. In their minds, incidents of workplace discrimination exemplified unequal work relationships between White co-workers and supervisors and Black care-assistants. On many occasions, their experiences of workplace discrimination were so 
pronounced that the carers' morale and self-esteem were negatively affected. As one Nigerian home carer said:

You meet a lot of them that would make you hate this job, that you can sit down and say, 'oh my God, I hate doing this job'.... You say, 'is it because I am Black or something?' Sometimes the way they would talk to you, the way they would treat you, you would hate yourself.

There were no formal support mechanisms or complaint channels to assist those who experienced racial discrimination at the workplace. Instead, they were required to resolve the situation themselves, which generally entailed either confronting the perpetrator directly or downplaying the significance of the event and trying to forget the incident. Some had received training intended to help them deal with any negative incidents which they encountered with care recipients. This training enabled them to contextualise negative remarks and actions (if made by a care recipient as opposed to a work colleague) as coming from someone with social, physical and emotional difficulties. As a male Nigerian nursing-home assistant said:

They [the residents] are not bad, you know they are here because of certain things, and that is why you are employed [to provide care], so you try as much as possible to go along with them, and everything is okay. You say to yourself, if I smile, you smile back, even if there is a bad response you know they are not in the right state of the mind.

The positive aspects of the work that were mentioned by the African carers were its flexibility and social or inter-personal dimensions. While the African interviewees encountered the most negative treatment from care recipients, managers or colleagues, paradoxically they were the most likely to speak about the positive aspects of their job and, in particular, to appreciate the close inter-personal relationships they fostered with the care recipients. Time, it was thought, usually permitted the carer and care recipient(s) to build a relationship of trust and overcome any existing prejudice or negative racial stereotyping. Even in nursing homes where care was delivered to as many as io people in one day, the development of close inter-personal relationships between the carer and care recipients was the norm. Far from being presented to us as the unidirectional 'provision of care', the carer-care recipient relationship was described as a mutually rewarding relationship with high levels of reciprocity. Similar to the respondents in McGregor's (2007) study, some held the impression that they were compensating for Irish family members who were perceived as having neglected their care responsibilities. The 'care contract' was in these instances seen as one of personal and human interaction and support. While the carers provided essential care, the care recipient in return 
offered friendship, a listening ear, advice and companionship for those who were distant from family and friends. As a South African home carer said:

I love them, I love them so much, because they make you feel very comfortable, and they appreciate everything you do for them and that really makes you feel like I've done something good ... that attachment it works between the two of you, even if you are two minutes late, you get worried, before she even worries, and I wonder if she is okay. If you walk in with a smile, and you see their smile, you feel really, really happy.

The Zimbabwean care workers in McGregor's (2007) United Kingdom study identified their work as frustrating, stressful and exploitative. While the African carers interviewed in our research were critical of discriminatory acts perpetrated by care recipients, work colleagues and managers, they generally did not characterise employment in the care sector in negative terms, nor viewed it as 'demeaning', 'dirty', 'cheap' or 'shameful' work, as McGregor found. The reasons for the more positive experiences in the Irish as compared with the UK long-term care sector are difficult to conjecture. In the absence of additional research it is impossible to identify whether these findings reflect a difference in employment conditions, or, a social desirability bias in our smaller sample of interviewees.

\section{South Asian carers}

Previous research on South Asian (Filipino) care workers has tended to focus on the issue of 'global care chains' (Hochschild 2000) and the migrants' care responsibilities towards their own family members in their country of origin (Parreñas 2000; Yeoh and Huang 2000). The focus of much of this research has been on domestic workers (nannies and maids) rather than domiciliary or institutional long-term care workers. While the issue of trans-national care responsibilities was particularly important for this group, for ease of analysis this article has exclusively examined employment in the care sector. With a few exceptions, the i7 interviewees from the Philippines tended to be older than their European or African counterparts. All had come to Ireland to work specifically in the care sector. Some had previously worked as live-in carers in Malaysia or Singapore, while others had worked in the Philippines in professions such as accounting, engineering, nursing and forestry. Most had secured employment in Ireland through an agency as child-minders and had subsequently accessed elder-care work through personal contacts. Ten of the interviewed Filipinas were live-in carers. Five worked in a formal capacity, having secured a work permit for this type of employment with 
the employer (presumptively) paying work-related social insurance contributions on their behalf. The other five were undocumented workers sourced in the 'grey' labour market.

The experiences of live-in care work, however, were similar for both the 'grey' labour market carers and the 'formal' carers. Both groups had loosely specified work contracts and, given their vulnerable legal status, limited scope to demand or secure improved work conditions or to seek alternative employment. For both groups of carers, the stability and security of their employment rested upon the care recipient's (and/or the care recipient's family's) satisfaction with their work and the care recipient's capacity to remain living at home. High demands and expectations were placed on the live-in carers. In addition to carrying out generic care-work duties, a number maintained the garden and acted as a domestic cleaner. Personal freedom was limited as they were expected to provide or be ready to provide care round-the-clock. Some felt obliged continually to shadow the care recipient for fear that something would happen to the person in their absence, with guilt and other adverse consequences being inevitably attached to them in the event of an accident. As a Filipina live-in carer said, 'when you bring her to bed, your mind is still there, even though you are off, you feel responsible. When I go shopping, my mind is still there, so I rush'.

For many, it was not the older cared-for person but their family that had unrealistic expectations of how much work the carer should do. In these instances, the family members were perceived to have a low regard for the carers and the work they undertook. While some did not have grievances with such extensive work requirements, others believed it was essential to be assertive in defining the boundaries of the job. Confronting the family and demanding improved work conditions did not usually result, however, in any significant change.

All of the Filipino institutional carers, while receiving higher rates of remuneration than the live-in domiciliary carers, spoke of their desire for greater remuneration. Institutional care work was perceived as being physically and emotionally demanding, particularly when caring for older people who were cognitively impaired or emotionally unstable. Verbal abuse or aggressive behaviour was mentioned by some working with people with dementia and those with cognitive and behavioural difficulties. Similar to the African interviewees, these carers had to develop individual coping strategies to deal successfully with such situations, given that in most instances there were no formal support mechanisms to which they could turn.

As with the African carers, the South Asian carers did not dwell on the negative aspects of their work and instead highlighted the positive 
relationships that formed with the care recipients. These relationships were frequently compared with the close bonds held currently or in the past with the interviewees' older relatives, such as parents or grandparents. In contrast to the African carers, however, many of these relationships were long term, ranging from three months to six years; the extended duration of the 'workplace' relationships stemmed largely from the South Asian carers' employment in live-in domiciliary care.

\section{European carers}

There is remarkably little research on the experience of European migrant care workers. Ungerson (2003, 2004) provided some information through her study of the introduction of 'cash-for-care' programmes in Europe. She referred to the 'grey' labour market and the employment of Hungarian and Slovakian care workers in Austria. These carers, who generally were young and satisfied with their work arrangements, often worked two-weeks-on/two-weeks-off, returning to their home countries when not working. In the Irish context, this situation has not arisen because of the long distances from mainland Europe.

None of the European care workers interviewed in our study had come to Ireland with the prior intention of working in care. In most cases, before arrival they had little knowledge of what work was available and no definite occupation in mind. They came to Ireland seeking employment, in the belief that salaries were higher than in their home countries. Securing employment on arrival was consequently a high priority. Immediate employment options were viewed to be limited to the 'Three Cs' of cleaning, caring and catering. Of these options, care work was viewed as being easily accessible and having the highest rates of remuneration. The majority had first entered the care sector for these two reasons. In contrast to both the South Asian and African carers, all but three had third-level educational qualifications, generally in health-related and social science disciplines.

The majority of the European carers assumed that past and current employment in the care sector would provide them with the necessary skills and experience to progress into more senior or otherwise more desirable jobs in (or outside) the care sector. For those who held thirdlevel qualifications in fields such as psychology and radiography, care work was seen as the optimum choice at that point in time (taking into account their poor proficiency in the English language and that their qualifications were not recognised). This group viewed the fact that their work involved a high degree of inter-personal contact and was in a healthcare setting as positive factors that to some extent compensated for the 
mismatch between their qualifications and the current job. As a Polish home carer said:

I'm a psychologist, and because I couldn't work in my profession in Ireland, I wanted to work with people, so I said, why not? This kind of job, it's some kind of psychology as well, you have to work with different people, with different mentalities, and it's good experience actually.

Another important consideration for the Polish, Lithuanian and Russian carers was that employment in the care sector provided an opportunity to improve their English language skills. As with the African carers, the European interviewees mentioned the flexibility of care work as an attraction. The negative aspects of care work that were mentioned tended to relate to particular aspects of the job as opposed to mistreatment by co-workers, care-recipients and management. Frustration was highest amongst those who worked in institutional settings, for many believed that they invested considerable effort in their work but received little recognition or acknowledgement. They felt that their work was not valued, respected or remunerated adequately, which in turn led to low job satisfaction. Low levels of appreciation and morale were the main issues voiced by those working in the private institutional care sector as opposed to the public sector. While the development of inter-personal relationships was mentioned as a positive aspect of care work, this facet of work was not alluded to as frequently by the European care workers as by the others. One likely explanation is that a higher proportion of the European interviewees worked in institutional care settings, where it was thought that there was little scope for the development of inter-personal relationships between carers and care recipients. The European interviewees seemed more transient than the South Asian and African care workers. With a few exceptions, the majority regarded employment in the longterm care field as entry-level work and were likely to say that it was temporary.

The two carers employed in the 'grey' labour market were anomalous among the European care workers. As with the African and Filipina carers employed in the 'grey' sector, they perceived their wages as too low and their work hours as unrealistic. Arising from their poor English language skills, one Polish interviewee, a qualified nurse, was forced to work in the 'grey' sector as a live-in carer. This carer's experience was in many ways similar to those of the Filipina live-in carers. However, unlike the Filipina interviewees, her legal status as an EU citizen granted her greater latitude to insist on improved terms and conditions. She remarked:

I was working every day full-time, day and night, about three months without a break. I was very tired. Then I told them [care recipient's daughter/family] 
I can't work 24 hours. ... I told them I want to work per [only in the] day and I want ... I need days off Saturday and Sunday. I got only Sunday off.

\section{Differences between African, South Asian and European care workers}

Negative experiences of care work were concentrated among specific groups of migrant care workers. In particular, African carers experienced the highest levels of prejudice and discrimination which they perceived as being largely racist. Such findings are a cause of concern and echo those of McGregor (2007) on Zimbabwean care workers in the UK. South Asian carers confronted different obstacles and discriminatory or exploitative work practices. Much of the discrimination they experienced was rooted in the informal nature of their work contracts and their illegal or conditional residency status, which put them in a relationship of dependency with their employers. Overall, the European care workers encountered least prejudice and discrimination. Compared with the African and South Asian interviewees, they were generally quite optimistic about their career progression. They found access to care work relatively easy and were confident about the possibility of moving horizontally and vertically within the care sector.

There were some commonalities, however, particularly among those working in institutional care settings. All groups described the work environment as physically demanding and at times demoralising and fraught with tension. Conversely, on the positive side, care work offered flexibility and (particularly in the domiciliary care context) permitted the development of close inter-personal relationships between the carer and care recipient. Indeed, almost all of those interviewed endorsed the latter point. A further commonality shared by all the carers was the satisfaction they derived from securing employment and having a regular income. For many, this economic security offset the negative aspects of care work and helped them maintain a positive attitude towards employment in the longterm care sector. The relatively small sample size prohibits the generalisation of the findings to the overall population of migrant care workers in Ireland. In particular, it is difficult to draw any substantial conclusions about the experiences of carers employed in the 'grey' labour market. Further research in this area is required to establish whether employment in the 'grey' sector is influenced by country or world region of origin. While it is possible that a carer's illegal employment status renders all 'grey' sector carers more vulnerable to mistreatment, it is more likely that those without residential legal rights (generally non-EU citizens) are at greater risk of exploitation (see Ungerson 2004; Degiuli 2007). 


\section{Conclusions}

Our understanding of the role of migrant care labour in long-term care systems in European and other developed countries is limited. This article is a first step towards understanding the experiences of migrant care workers. They are often perceived as homogeneous, but even this initial study shows a great diversity of experiences and the possibility that there are systematic variations by region of origin. It is conceivable that some of the findings outlined here may be replicated in other countries that have immigrant care workers. Acknowledging that specific groups of migrant carers confront different obstacles and barriers that impact negatively upon their work is an essential first step, from which policy and practical interventions can be developed to combat discrimination and to support all members of the migrant long-term care workforce. While our study was not able to focus on care recipients' perceptions of the multi-cultural care workforce, studies that analyse the interaction of migrant carers and (in many cases also increasingly diverse groups of) care recipients are evidently also needed.

The profile of the long-term care workforce in European countries is likely to change further in the coming decades, but will continue to be influenced by, among other things, specific aspects of a country's longterm care system, the geographical proximity of available migrant carers and binding agreements between countries relating to the free movements of people. The entry of io Eastern European countries into the European Union (EU) in 2004, the accession of Bulgaria and Romania in 2007 and the EU obligation of 'community preference'"2 may lead to a rise in the proportion of the workforce that originates from EU member states. Notable trends across Europe, such as the expansion of privatesector long-term care (Doyle and Timonen 2007), the increase in 'cash-for care' schemes (Ungerson 2004; Timonen, Cahill and Convery 2006; Ungerson and Yeandle 2007), and the possible expansion of the 'grey' care labour market (Ungerson 2004), are all likely to generate demand for migrant women who are willing to work at (or close to) the minimum wage or indeed for less. As the economic conditions of the new accession countries converge with those of the older member states, the willingness of EU carers to work in such low wage jobs may fall. In this eventuality, the demand for non-EU carers, typically from developing countries in Africa, South Asia and South America, will rise again. In the absence of regulations that aim to protect all members of the care workforce (including the hidden population of live-in carers), the emergence of a more unequal and segmented long-term care workforce is virtually inevitable. 


\section{NOTES}

I McGinnity et al. (2006) conducted a quantitative study in 2005 with I, Iog migrants living in Ireland. They found that South/Central Africans encountered the highest levels of discrimination when accessing employment, followed by Asians and East Europeans, and that harassment at work was experienced more frequently among African and East European workers than Asian workers.

2 As outlined in the European Union Accession Treaty of 16 April 2003, which as regards the Member States' labour markets, gives preference to workers who are EU nationals over workers who are nationals of third countries.

\section{References}

Ahern, D., Doyle, M. and Timonen, V. 2007. Regulating home care of older people: the inevitable poor relation? Dublin University Law Fournal, 29, 374-96.

Anderson, B. 2006. A Very Private Business: Migration and Domestic Work. Working Paper 28, Centre on Migration, Policy and Society, University of Oxford, Oxford.

Anderson, B. and Rogaly, B. 2005. Forced Labour and Migration to the UK. Centre for Migration, Policy and Society (COMPAS), Oxford, in association with the Trades Union Congress, London.

Bakan, A. B. and Stasiulis, D. I995. Making the match: domestic placement agencies and the racialisation of women's work. Signs: Fournal of Women in Culture and Society, 2o, 2, 303-35.

Central Statistics Office 2005. Statistical Yearbook of Ireland 2005. Central Statistics Office, Dublin.

Daatland, S. O. and Lowenstein, A. 2005. Intergenerational solidarity and the family welfare state balance. European Fournal of Ageing, 2, 3, 174-82.

Degiuli, F. 2007. A job with no boundaries: home eldercare work in Italy. European fournal of Women's Studies, I4, 3, 193-207.

Doyle, M. 2006. The market: role in provision of home care. In Timonen, V., Doyle, M. and Prendergast, D. (eds), No Place Like Home, Domiciliary Care Services fo Older People in Ireland. Liffey Press, Dublin, I I5-76.

Doyle, M. and Timonen, V. 2007. Home Care for Ageing Populations: A Comparative Analysis of Domiciliary Care in Denmark, Germany and the United States. Edward Elgar, Cheltenham, Gloucestershire, UK.

European Foundation for the Improvement of Living and Working Conditions 2006. Employment in Social Care in Europe. European Foundation for the Improvement of Living and Working Conditions, Dublin.

Hondagneu-Sotelo, P. 200o. The international division of caring and cleaning work. In Harrington, M. H. (ed.), Care Work: Gender, Class and the Welfare State. Routledge, New York, I49-62.

Hochschild, A. R. 2000. Global care chains and emotional surplus value. In Hutton, W. and Giddens, A. 2000 (eds), On the Edge: Living with Global Capitalism. Jonathan Cape, London, $\mathrm{I}^{3} \mathrm{O}-46$.

Irish Nursing Home Organisation (INHO) 2006. Annual Private Nursing Home Survey 2006. INHO, Dublin.

McGinnity, F., O’ Connell, P. J., Quinn, E. and Williams, J. 2006. Migrants' Experience of Racism and Discrimination in Ireland. Results of a survey conducted by the Economic and Social Research Institute for the European Union Monitoring Centre on Racism and Xenophobia, Economic and Social Research Institute, Dublin.

McGregor, J. 2007. Joining the BBC (British bottom cleaners): Zimbabwean migrants and the UK care industry. Fournal of Ethnic and Migration Studies, 33, 5, 80I-24. 
Organisation for Economic Co-operation and Development (OECD) 2005. The OECD Health Project: Long-term Care for Older People. OECD, Paris.

Parreñas, S. R. 2000. Migrant Filipina domestic workers and the international division of reproductive labor. Gender and Society, I4, 4, 560-8I.

Pope, C., Ziebland, S. and Mays, N. 200o. Qualitative research in health care: analysing qualitative data. British Medical Fournal, 8, 320 (7227), I I4-6.

Stone, R. I. and Wiener, J. M. 200I. Who Will Care for Us? Addressing the Long-Term Care Workforce Crisis. The Urban Institute and the American Association of Homes and Services for the Ageing, Washington DC.

Timonen, V., Convery, J. and Cahill, S. 2006. Care revolutions in the making? A comparison of cash-for-care programmes in four European countries. Ageing E' Society, 26, 3 , $455^{-74}$.

Ungerson, C. 2003. Commodified care work in European Labour markets. Fournal of European Societies, I 5, 4, 377-96.

Ungerson, C. 2004. Whose empowerment and independence? A cross-national perspective on 'cash for care' schemes. Ageing \& Society, 24, 2, I89-212.

Ungerson, C. and Yeandle, S. 2007. Cash for Care Systems in Developed Welfare States. Palgrave Macmillan, New York.

US Bureau of Labour Statistics 2005. Occupational Employment Statistics May 2005. Bureau of Labor Statistics, Department of Labor, Washington DC.

Yeates, N. 2005. Global Care Chains: A Critical Introduction. Global Migration Perspectives 4, Global Commission on International Migration, Geneva, Switzerland. Available online at http://www.gcim.org/attachements/GMP\%20No\%2044.pdf [Accessed June 2008].

Yeoh, B. S. A. and Huang, S. 200o. Home and away: foreign domestic workers and negotiations of diasporic identity in Singapore. Women's Studies International Forum, 23, 4 , 413-29.

Address for correspondence:

Accepted 26 June 2008

Martha Doyle, Social Policy and Ageing Research Centre, School of Social Work and Social Policy, Trinity College Dublin, Dublin 2, Ireland.

E-mail: martha.doyle@tcd.ie. 